\title{
Grant Principal Investigator
}

National Cancer Institute

\section{Source}

National Cancer Institute. Grant Principal Investigator. NCI Thesaurus. Code C51826.

An individual designated by the grantee to direct the project or activity being supported by the grant. He or she is responsible for the scientific, legal, administrative, and technical aspects of the grant and accountable to the grantee for the proper conduct of the project or activity. The Principle Investig ator (PI) must have a formal written appointment with the applicant organization, which must be in the form of an official relationship between the parties, but need not involve a salary or other form of remuneration. The PI is a member of the grantee team responsible for ensuring compliance with the financial and administrative aspects of the award and with org anizational as well as Federal requirements. 